\title{
Spatial economic attributes of O.R. Tambo and Cape Town airport-centric developments in South Africa
}

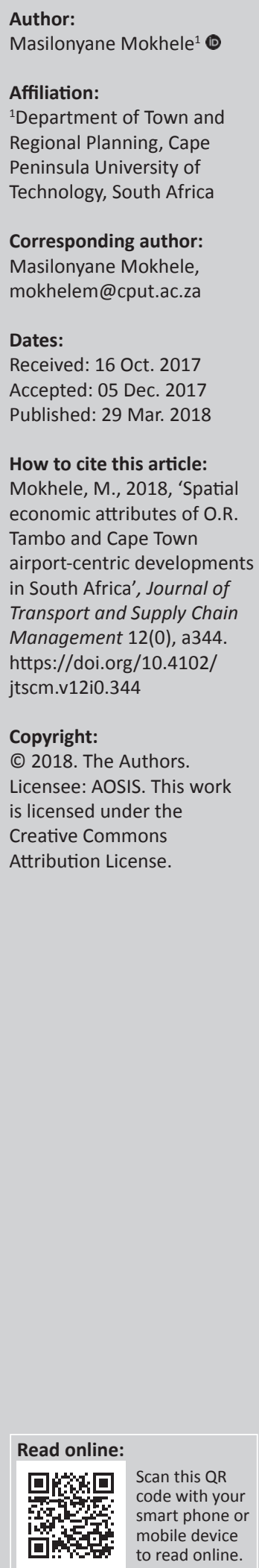

Background: The concentration of development around airports is a topical subject on the relationship between transportation, accessibility and the distribution of land use. Notwithstanding the existing literature on the analysis of airports and surrounds, and normative models of airport-led development, extensions are required on the empirical analysis of spatial economic attributes of airports and surrounds.

Objectives: Objectives of the article were twofold: firstly, to establish the economic activity mix and reasons for the location of firms on and around O.R. Tambo and Cape Town international airports; and secondly, to analyse linkages between firms on and around the two airports as well as linkages those firms have with their metropolitan, regional, national and international contexts.

Method: The article focused on the South African case studies of O.R. Tambo and Cape Town international airports and used a telephone survey as the primary data collection method.

Results: The article discovered that the developments around O.R. Tambo and Cape Town international airports are spatial clusters that are also linked with other airports in South Africa and beyond.

Conclusion: The article extended existing knowledge by providing insights on the spatial economic characteristics of airports and surrounds. The findings can be improved upon with work on other case studies, and potentially be used as bases for extending a theoretical framework that describes and explains the spatial economic forces that drive development on and around airports.

\section{Introduction}

Literature on the nexus between transportation and land use focuses on, among others, the empirical analyses of the spatial economic attributes of airports and surrounds and normative planning models that propose the idealised spatial form and economic activity mix of airport environs (see literature overview hereunder). Notwithstanding the varied insights of literature, it could be argued that extensions are required on the empirical analysis of spatial economic attributes of airports and surrounds, with a particular focus on transport-oriented firms. The aim of this article is therefore to investigate the spatial economic attributes (specifically the driving forces) of the environs of O.R. Tambo and Cape Town international airports in South Africa. The specific objectives of the article are twofold, namely: one, to establish the economic activity mix and reasons for the location of firms on and around O.R. Tambo and Cape Town international airports; and two, to analyse the linkages between firms on and around the two airports as well as linkages those firms have with their metropolitan, regional, national and international contexts.

As is evident in the objectives mentioned above, the article largely uses the term 'firm' as opposed to, for instance, land uses or industries. This decision was taken so as to permit a logical identification of the study's units of analysis (see the Research Methodology section), given that a firm represents an individual legal entity as opposed to land use or industry, which compromise a number of firms. It should also be noted that from the Research Methodology section onwards, the article makes reference to 'airport-centric firms' and 'airport-centric developments'. For the purposes of this article, airport-centric firms are firms that are located: firstly, around the airport, that is, at areas located in the geographical proximity of (and contiguous with) the airport, but outside the airport premises; secondly, on the airport's land, but not within the terminal; and

Note: This article is partially based on the author's dissertation for the degree of Doctor of Philosophy at the Faculty of Arts and Social Sciences, Stellenbosch University, South Africa, with supervisor Prof. Hermanus Stephanus Geyer, received March 2016. 
thirdly, within the airport's terminal. For a given airport environs, a totality of airport-centric firms as defined above is referred to as airport-centric development.

\section{Literature overview and conceptual frame of reference}

Theoretical, policy and empirical discussions on the relationship between transportation and land use often recognise that airports can influence the spatial distribution of land use. The wealth of literature that informs that assertion can be categorised into five related themes, namely:

- the effects of aircraft and airport noise, as synthesised by Mestre (2008)

- the economic benefits of airports, commonly documented in airport economic impact reports (see Karlsson et al. [2008] for a synthesis)

- models that propose the ideal spatial form and mix of developments emanating from airports (for a thorough overview, see Freestone and Baker [2011])

- the institutional arrangements that influence airport development (for instance, see De Jong, Suau-Sanchez \& Droß 2008; Galvin 2010; Knippenberger 2010, 2015; Van Boxtel \& Huys 2005; Van Wijk 2007, 2008; Walker \& Barker 2010)

- the spatial economic attributes of airports and surrounds, including analyses of land-use composition and factors that influence location choice decisions of firms (see, for example, Appold 2015; Appold \& Kasarda 2013; Coetzee \& Swanepoel 2017; Conventz 2010; Giuliano \& Small 1991, 1999; Hoare 1974, 1975; Keeble 1968; McMillen \& McDonald 1998; Prosperi 2007, 2008; Rogerson 1998; Shukla \& Waddell 1991; Sivitanidou 1996; Sohn 2004; Vahaly 1976; Van Wijk 2007; Warffemius 2007).

Two considerations pertaining to the strands of literature above are worth highlighting. Firstly, the normative models of the so-called airport-led development are continuously and rapidly gaining currency across the world. They are promoted by, inter alia, airport authorities, developers and governments as economically and physically integrated initiatives of the airport and urban development (Schlaack 2010). Such models include airport city (Conway 1993; Kasarda 2009), aerotropolis (Kasarda 2009; Kasarda \& Lindsay 2011), airport region (Schlaack 2010), airfront (Blanton 2004), global transpark (Kasarda 1998; Sit 2004), airport corridor (Schaafsma 2003, cited in Schlaack 2010), airea (Schlaack 2010), decoplex (Conway 1993), aircity, aeropolis, aeropark, aviopolis, avioport, flight forum, sky city, airpark, aero city and aeroscape. Among the aforementioned models, airport city and aerotropolis are the most dominant in the literature and in practice. Airport cities are used worldwide to envision the growth of aviation and nonaviation activities on and around airports (Walker \& Stevens 2008), because of their dependence on airports. According to Kasarda (2009), as more economic activities are attracted to airport cities and along the transportation infrastructure linking such developments, a new urban form develops.
Referred to as an aerotropolis, the envisaged urban form consists of developments that could extend up to approximately $30 \mathrm{~km}$ from airports (see, for instance, Kasarda \& Lindsay 2011). Secondly, and relatedly, the empirical analyses of the spatial economic attributes of airports and surrounds are particularly crucial in equipping planners with a comprehensive understanding of the workings of airports and their surrounds. Such understanding can ensure that planning initiatives pertaining to airport environs are appropriately conceived, formulated and directed.

Notwithstanding the significance of the existing knowledge, the majority of the two noteworthy sets of literature above at least in part, insufficiently consider the fundamental concepts of agglomeration economies, linkages and clustering. These concepts have been central throughout the history of human geography, economics and related disciplines as regards analyses of the location of economic activity, and are thus regarded as potential cornerstones of the analysis of airports and their surrounds. The alleged limitation is discussed at great lengths elsewhere in literature and is thus not covered herein because of limited space. However, because the concepts of agglomeration economies, linkages and clustering are susceptible to multiple interpretations, the article's position is clarified hereunder.

Agglomeration economies consist partly of internal economies and partly of external economies (Jofre-Monseny, Marín-López \& Viladecans-Marsal 2011, 2014; Ottaviano \& Thisse 2004; Parr 2002; Rosenthal \& Strange 2003). The economies internal to the firm are controlled by the firm and are not (directly) affected by the actions of other firms and can be classified into economies of scale, scope and complexity. Internal economies of scale, also known as economies of horizontal integration, refer to benefits to the firm that result from increases in the extent of its operations. Internal economies of scope (lateral integration) are realised because of the diversity of products and/or services provided by the firm. The notion of economies of scope is based upon the understanding that the joint undertaking by a firm of two or more activities could occur more efficiently than would be the case if separate firms undertook such activities (Panzar \& Willig 1981; Parr 2002; Scott 1988). The internal economies of complexity (vertical integration) refer to the multi-process of production and more generally to the fact that the activities of a firm involve separable stages. Economies of complexity therefore occur when the undertaking of various stages by a single firm results in lower total costs (or efficiency generally) for the end product or service than would be the case if separate firms carried out the stages. Agglomeration economies based on internal economies typically, but not necessarily, result in individual firms becoming larger (Parr 2002).

Comprising localisation, urbanisation and activity-complex economies, external economies are dependent on the existence and actions of other agglomerated firms. Localisation economies, as originally explained by Marshall (1920), derive from the common location of independent firms in the same 
industry while urbanisation economies are typical of diversified urban areas and result from the common location of firms involved in different and unrelated economic activities (Isard 1956; Krupka 2009; Parr 2002). The latter is the result of the use of a diverse set of available urban facilities and services including transportation facilities such as airports. Activity-complex economies result from the common location of a set of firms that exist in a production or service provision chain so as to form an activity complex. Numbers and volumes of upstream linkages serving the demand sides, and downstream linkages serving the supply sides of firms that form part of such activity complexes are crucial in determining their spatial economic significance (Karlsson, Johansson \& Stough 2005; Malmberg \& Maskell 2002; Porter 1990; Rosenthal \& Strange 2003; Venables 1996). In addition to agglomeration economies, the article investigates dispersion economies, which occur when firms disperse their activities away from the head office (Polenske 2008).

Linkages are required for the realisation of agglomeration and dispersion economies outlined above. Linkages refer to the flows of information, materials and/or services between firms and flows within a firm. A firm's linkages can be classified into three categories: firstly, backward linkages, which provide goods and services as input for its activities or output; secondly, forward linkages, which provide links with customers purchasing its products or services. The terms backward and forward linkages are synonyms for upstream and downstream linkages as shown in the discussion above of activity-complex economies. If businesses are linked through an input-output (buyer and supplier) structure, the downstream industry forms the market for the upstream industry (Malmberg \& Maskell 2002; Porter 1990; Venables 1996). The firms in the vertical arrangement are therefore business partners and collaborators (Malmberg \& Maskell 2002). The third category pertains to sideways, lateral or horizontal linkages, which are interactions with other firms involved in the same processes that share the customers and technology (Porter 1990). The horizontal dimension consists of rivals and competitors, given that the firms share the same market (Malmberg \& Maskell 2002).

The existence of linkages can result in two forms of clusters, namely: spatial clusters, denoting linked firms located in the same geographical area; and organisational clusters, denoting firms that are linked, regardless of their separate geographical locations. Spatial clusters are influenced by agglomeration economies. Clustering can be based on internal and/or external economies. As regards internal economies, when a head office of a firm has functional linkages with multiple units of the same firm - regional headquarters and production units, for instance - whether located within the same geographical area, city, country or even across national borders, such a situation would be understood as organisational clustering resulting from internal economies of scale, scope and/or complexity. However, there might be instances where operations of the subsidiaries of multi-locational firms do not have significant linkages, thus not creating a cluster.
Against the background of literature and underlying concepts discussed above, the objectives of the article are to establish the economic activity mix and reasons for the location of firms on and around O.R. Tambo and Cape Town international airports; and to analyse the linkages between firms on and around the two airports as well as linkages those firms have with their metropolitan, regional, national and international contexts.

Towards achieving the research objectives, the article introduces a new analytical approach, which explores interconnections between the underlying concepts of linkages, agglomeration economies and clustering; and the relationally interpreted concepts of economic space, proximity and firm insofar as they have relevance to airports and their surrounds. Upon those intricate interconnections, which are explored on the background of a globalising world, the industrial cluster concept is used as the primary framework for analysing the spatial economic attributes of airports and surrounds.

\section{Research methodology}

The study deployed mixed research methods that encompassed qualitative and quantitative approaches and based upon a combination of primary and secondary sources of information. The study particularly employed triangulation as a type of mixed method approach, based on the argument that observing phenomena from different perspectives yields a more comprehensive view (see Neuman 2000). The methods used to collect data were based predominantly on a descriptive survey, qualitative interviews and secondary sources where relevant.

Despite the availability of a multitude of terms and models of airport-led development overviewed earlier, the article adopts a fairly neutral concept of 'airport-centric development' to refer to a collective of 'airport-centric firms'. Airportcentric firms are firms that are located: firstly, around the airport, that is, at areas located in the geographical proximity of (and contiguous with) the airport, but outside the airport premises; secondly, on the airport's land; and thirdly, within the airport's terminals. These three components were adopted as the levels of analysis, which are elements of reality to which descriptions and explanations in research refer. The units of analysis, which denote the units a researcher uses when investigating a phenomenon (see Neuman 2000), were the individual firms located within the three levels of analysis.

The research was based upon a case study approach, which is commonly defined as research in which analyses are undertaken on a phenomenon that is bounded by activity (Leedy \& Ormrod 2010). Airport-centric development is a phenomenon defined by virtue of being located in the geographical proximity of airports. This attribute of physical proximity to airports made a case study approach appropriate towards addressing the aim and objectives of the study. The study focused on the South African case studies of O.R. 
Tambo International Airport and Cape Town International Airport and their immediate surrounds (Figures 1 and 2 portray the extent of the case study areas, including the associated levels of analysis). In comparison to other airports in South Africa, Cape Town and O.R. Tambo international airports are surrounded by substantial and diverse concentrations of economic activity; hence, they were selected as befitting case studies for exploring the spatial economic characteristics of airport-centric developments.

\section{Overview of the case study areas}

Opened in 1952, O.R. Tambo International Airport is located in Ekurhuleni municipality, Gauteng province and serves the Gauteng city-region including the country's wealthiest city, Johannesburg, and the administrative capital city, Pretoria. The airport is part of a multi-airport system in the city-region, including Lanseria, Rand, Grand Central and Wonderboom airports. As South Africa's busiest airport, it handled 336604 tonnes of cargo in 2017 (P. Makhetha [ACSA], pers. Comm., 02 March 2018), and facilitates approximately 20 million passengers per annum (Airports Company South Africa [ACSA] 2018a). Established in 1954, Cape Town International Airport is located in the City of Cape Town municipality, Western Cape province. As the second busiest airport in South Africa, it handles over 10 million passengers per annum (ACSA 2018b), and it processed 69216 tonnes of cargo in 2017 (P. Makhetha [ACSA], pers. Comm., 02 March 2018).

\section{Firm collation, sampling and data collection methods}

For purposes of this study, and per the definition of airportcentric development adopted, O.R. Tambo and Cape Town airports and their environs were each categorised into three levels of analysis, namely: areas around the airport, the landside (airport premises) and terminals (see Figures 1 and 2).

The O.R. Tambo airport-centric firms were recorded from a variety of complimentary sources, viz. searches on the online business database of http://www.yellowpages.co.za (Trudon 2013); the online business database of http:/ / www. brabys.com; business database from Ekurhuleni municipality, compiled as part of the aerotropolis initiative (A. Engar [Ekurhuleni municipality], pers. comm., 08 May 2013); business database (known as datadex) on the website of the East Rand Chamber of Commerce (2014); the website of http:/ /www.kemptalk.com (Van Wyk 2013); Google Maps; and business information from ACSA pertaining to firms within the airport terminals (C. Flayser [ACSA], pers. comm., 09 May 2013), supplemented with company information available on ACSA's website (ACSA 2014b).

At the Cape Town case studied, methods that were used to record the firms across the said levels of analysis included a triangulation of: land-use information from the City of Cape Town municipality; the 2013/2014 Cape Peninsula telephone book (Trudon 2012a); the 2013/2014 Yellow Pages (Trudon 2012b) and the associated online business database of http://www.yellowpages.co.za; Google Maps; business database on the Airport Industria City Improvement District's (CID) website (Airport Industria CID 2013); Cape Town Chamber of Commerce's online company database (Cape Town Chamber of Commerce 2014); and business database from ACSA pertaining to firms within the airport terminals (L. Thethiwe [ACSA], pers. comm., 15 June 2013), referenced against company information available on ACSA's website (ACSA 2014a).

In order to draw a stratified random sample at each case studied, the firms recorded were categorised in terms of Statistics South Africa's (2012) standard industrial classification of economic activities (SIC) sections (see Table 1 in the Research Findings section), which served as strata. Subsequent to the sampling process, and using the sampled individual airportcentric firms as units of analysis, primary data were collected between September 2014 and August 2015 through a telephone survey. Depending on their willingness to participate, the firms' representatives were asked to respond to a questionnaire accommodating a range of open and closed-ended questions with each interview lasting a maximum of about $5 \mathrm{~min}$.

Representing a confidence level of 95\% (at 5\% interval) per case studied, 311 O.R. Tambo airport-centric firms and 212 Cape Town airport-centric firms participated in the survey. For the purposes of analysis (and the subsequent presentation of findings), the respondent firms were reclassified (i.e. changed from SIC sections) per the following six categories: manufacturing; transport, storage and related activities; wholesale and retail; accommodation and catering; car repair and related activities; and other. This reclassification was carried out to circumvent the various potential pitfalls of analyses that are based on SIC categories (for instance, see a thorough discussion by Smith 1977).

To supplement the survey data, face-to-face interviews were conducted with six O.R. Tambo airport-centric firms, and two interviews (one face-to-face and one telephonic) were conducted with Cape Town airport-centric firms. As they were not intended to be representative of the cases studied, these eight firms were selected purposefully. It is important to note that the limited number of the qualitative interviews conducted was also influenced by the willingness and ability of the firms to participate. However, the low number did not have an adverse impact on the quality of the study given that it was essentially survey research, which achieved statistically significant response rates above, implying that the overall population is likely to have characteristics of the sample investigated.

\section{Analytical strategy}

As a guiding analytical strategy, the concepts of linkages, agglomeration economies and clustering were used to explore interconnections with the relationally interpreted concepts of space, firm and proximity. As noted earlier, these concepts are critical for a comprehensive analysis of airportcentric developments. The data from the survey were entered into the computer programmes of Microsoft Excel and IBM 


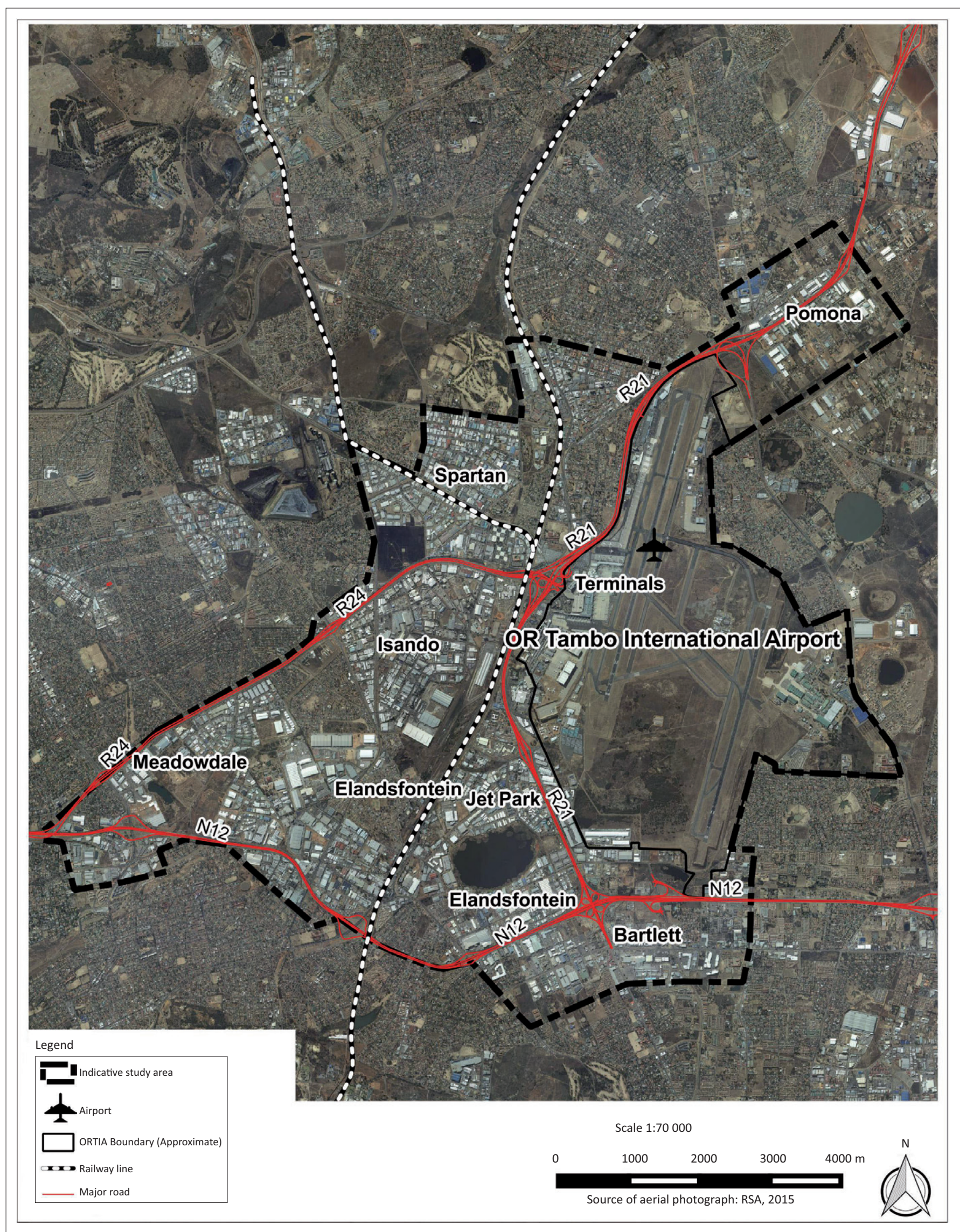

Source: Mokhele, M., 2017, 'Spatial economic evolution of the airport-centric developments of Cape Town and OR Tambo international airports in South Africa', Town and Regional Planning 70, 26-36, viewed 15 December 2017, from http://journals.ufs.ac.za/index.php/trp/article/view/593

FIGURE 1: O.R. Tambo airport-centric development. 


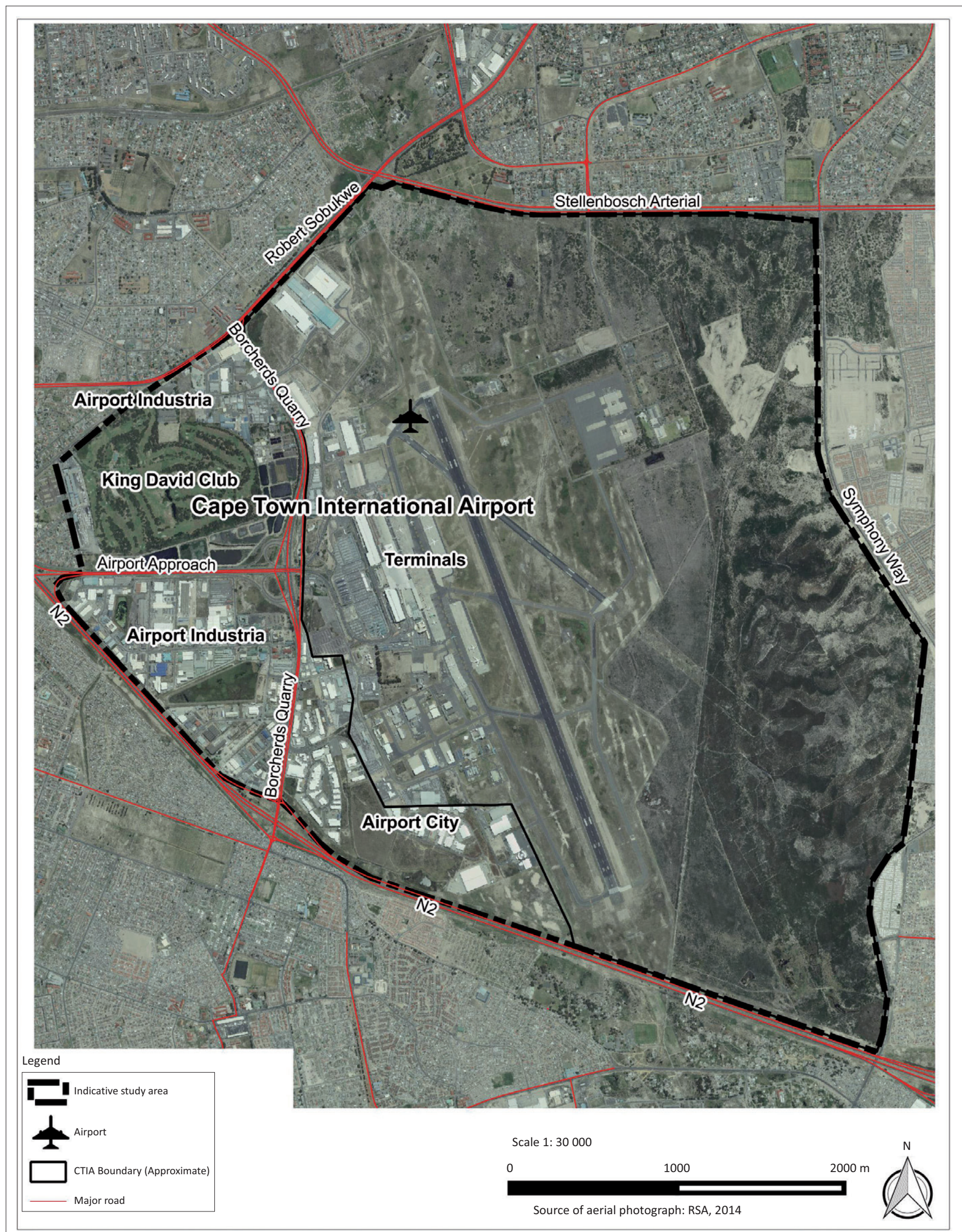

Source: Mokhele, M., 2017, 'Spatial economic evolution of the airport-centric developments of Cape Town and OR Tambo international airports in South Africa', Town and Regional Planning 70, 26-36, viewed 15 December 2017, from http://journals.ufs.ac.za/index.php/trp/article/view/593

FIGURE 2: Cape Town airport-centric development. 
TABLE 1: Mix of O.R. Tambo and Cape Town airport-centric developments.

\begin{tabular}{|c|c|c|c|c|c|c|c|c|c|}
\hline \multirow[t]{2}{*}{ SIC category } & \multirow[t]{2}{*}{ Frequency } & \multicolumn{3}{|c|}{ O.R. Tambo levels of analysis } & \multirow{2}{*}{$\begin{array}{c}\text { O.R. Tambo } \\
\text { total }\end{array}$} & \multicolumn{3}{|c|}{ Cape Town levels of analysis } & \multirow{2}{*}{$\begin{array}{l}\text { Cape Town } \\
\text { total }\end{array}$} \\
\hline & & Around airport & Landslide & Terminals & & Around airport & Landside & Terminals & \\
\hline \multirow[t]{2}{*}{ Manufacturing } & Count & 347.0 & 1.0 & 0.0 & 348.0 & 50.0 & 3.0 & 0.0 & 53.0 \\
\hline & $\%$ of Total & 21.3 & 0.1 & 0.0 & 21.4 & 10.8 & 0.7 & 0.0 & 11.5 \\
\hline \multirow{2}{*}{$\begin{array}{l}\text { Electricity, gas, steam and air conditioning } \\
\text { supply }\end{array}$} & Count & 1.0 & 0.0 & 0.0 & 1.0 & 0.0 & 0.0 & 0.0 & 0.0 \\
\hline & $\%$ of Total & 0.1 & 0.0 & 0.0 & 0.1 & 0.0 & 0.0 & 0.0 & 0.0 \\
\hline \multirow{2}{*}{$\begin{array}{l}\text { Water supply, sewerage, waste management } \\
\text { and remediation activities }\end{array}$} & Count & 4.0 & 0.0 & 0.0 & 4.0 & 4.0 & 0.0 & 0.0 & 4.0 \\
\hline & $\%$ of Total & 0.2 & 0.0 & 0.0 & 0.2 & 0.9 & 0.0 & 0.0 & 0.9 \\
\hline \multirow[t]{2}{*}{ Construction } & Count & 25.0 & 0.0 & 0.0 & 25.0 & 9.0 & 0.0 & 0.0 & 9.0 \\
\hline & $\%$ of Total & 1.5 & 0.0 & 0.0 & 1.5 & 2.0 & 0.0 & 0.0 & 2.0 \\
\hline \multirow{2}{*}{$\begin{array}{l}\text { Wholesale and retail trade; repair of motor } \\
\text { vehicles and motorcycles }\end{array}$} & Count & 479.0 & 4.0 & 76.0 & 559.0 & 82.0 & 41.0 & 46.0 & 169.0 \\
\hline & $\%$ of Total & 29.4 & 0.2 & 4.7 & 34.3 & 17.8 & 8.9 & 10.0 & 36.7 \\
\hline \multirow[t]{2}{*}{ Transportation and storage } & Count & 327.0 & 56.0 & 46.0 & 429.0 & 106.0 & 1.0 & 24.0 & 131.0 \\
\hline & $\%$ of Total & 20.1 & 3.4 & 2.8 & 26.3 & 23.0 & 0.2 & 5.2 & 28.4 \\
\hline \multirow[t]{2}{*}{ Accommodation and food service activities } & Count & 48.0 & 3.0 & 23.0 & 74.0 & 9.0 & 2.0 & 12.0 & 23.0 \\
\hline & $\%$ of Total & 2.9 & 0.2 & 1.4 & 4.5 & 2.0 & 0.4 & 2.6 & 5.0 \\
\hline \multirow[t]{2}{*}{ Information and communication } & Count & 8.0 & 1.0 & 0.0 & 9.0 & 7.0 & 0.0 & 0.0 & 7.0 \\
\hline & $\%$ of Total & 0.5 & 0.1 & 0.0 & 0.6 & 1.5 & 0.0 & 0.0 & 1.5 \\
\hline \multirow[t]{2}{*}{ Financial and insurance activities } & Count & 8.0 & 2.0 & 10.0 & 20.0 & 1.0 & 0.0 & 4.0 & 5.0 \\
\hline & $\%$ of Total & 0.5 & 0.1 & 0.6 & 1.2 & 0.2 & 0.0 & 0.9 & 1.1 \\
\hline \multirow[t]{2}{*}{ Real estate activities } & Count & 3.0 & 0.0 & 0.0 & 3.0 & 0.0 & 0.0 & 0.0 & 0.0 \\
\hline & $\%$ of Total & 0.2 & 0.0 & 0.0 & 0.2 & 0.0 & 0.0 & 0.0 & 0.0 \\
\hline \multirow[t]{2}{*}{ Professional, scientific and technical activities } & Count & 51.0 & 0.0 & 1.0 & 52.0 & 8.0 & 14.0 & 0.0 & 22.0 \\
\hline & $\%$ of Total & 3.1 & 0.0 & 0.1 & 3.2 & 1.7 & 3.0 & 0.0 & 4.8 \\
\hline \multirow[t]{2}{*}{ Administrative and support service activities } & Count & 44.0 & 18.0 & 0.0 & 62.0 & 27.0 & 1.0 & 2.0 & 30.0 \\
\hline & $\%$ of Total & 2.7 & 1.1 & 0.0 & 3.8 & 5.9 & 0.2 & 0.4 & 6.5 \\
\hline \multirow{2}{*}{$\begin{array}{l}\text { Public administration and defence; compulsory } \\
\text { social security }\end{array}$} & Count & 0.0 & 1.0 & 0.0 & 1.0 & 0.0 & 2.0 & 0.0 & 2.0 \\
\hline & $\%$ of Total & 0.0 & 0.1 & 0.0 & 0.1 & 0.0 & 0.4 & 0.0 & 0.4 \\
\hline \multirow[t]{2}{*}{ Education } & Count & 19.0 & 0.0 & 0.0 & 19.0 & 6.0 & 0.0 & 0.0 & 6.0 \\
\hline & $\%$ of Total & 1.2 & 0.0 & 0.0 & 1.2 & 1.3 & 0.0 & 0.0 & 1.3 \\
\hline \multirow[t]{2}{*}{ Human health and social work activities } & Count & 11.0 & 0.0 & 0.0 & 11.0 & 0.0 & 0.0 & 0.0 & 0.0 \\
\hline & $\%$ of Total & 0.7 & 0.0 & 0.0 & 0.7 & 0.0 & 0.0 & 0.0 & 0.0 \\
\hline \multirow[t]{2}{*}{ Arts, entertainment and recreation } & Count & 2.0 & 0.0 & 0.0 & 2.0 & 0.0 & 0.0 & 0.0 & 0.0 \\
\hline & $\%$ of Total & 0.1 & 0.0 & 0.0 & 0.1 & 0.0 & 0.0 & 0.0 & 0.0 \\
\hline \multirow[t]{2}{*}{ Other service activities } & Count & 10.0 & 0.0 & 0.0 & 10.0 & 0.0 & 0.0 & 0.0 & 0.0 \\
\hline & $\%$ of Total & 0.6 .0 & 0.0 & 0.0 & 0.6 & 0.0 & 0.0 & 0.0 & 0.0 \\
\hline \multirow[t]{2}{*}{ Total } & Count & 1387.0 & 86.0 & 156.0 & 1629.0 & 309.0 & 64.0 & 88.0 & 461.0 \\
\hline & $\%$ of Total & 85.1 & 5.3 & 9.6 & 100.0 & 67.0 & 13.9 & 19.1 & 100.0 \\
\hline
\end{tabular}

Source: Adapted from Mokhele, M., 2016, 'Spatial economic attributes of airport-centric developments in Cape Town and Johannesburg', Doctoral dissertation, Stellenbosch University, Stellenbosch SIC, standard industrial classification of all economic activities.

Statistical Package for Social Sciences (SPSS, version 23) for determining frequency distributions, cross-tabulations, calculation of correlations and measures of central tendency. Information from the qualitative interviews was transcribed and used to supplement the survey data where pertinent.

\section{Research findings \\ Mix of airport-centric developments}

In 2014, 1629 firms were recorded at the O.R. Tambo airportcentric development, dominated by wholesale and retail trade firms, followed by transportation and storage firms (see Table 1). At the Cape Town airport-centric development, a population of 461 firms was recorded in the same year wherein wholesale and retail trade firms, followed by transportation and storage firms, dominated the mix (Table 1). These findings point to the prominence of logistics firms within the economic activity mix of the cases studied. It should be noted that for the purposes of this article, the terms 'logistics', 'transport-oriented' and 'transportation and storage' are used interchangeably. These categories primarily comprise couriers, airlines, freight forwarders, warehousing or storage, and trucking firms.

\section{Employment size and forces of attraction}

Using the number of employees as a basic measure of firm size, it was discovered that $12 \%$ of O.R. Tambo airport-centric firms and $9 \%$ of Cape Town airport-centric firms are large. The determination of firm size was based upon the guidelines set by South Africa (1996), which classifies the size of firms in terms of three categories, number of employees, total annual turnover and total gross asset value. In terms of employees, sizes of firms are indicated according to the SIC categories. However, South Africa (1996) does not make reference to large firms, but only discusses the ceiling number of employees required for a firm to be classified as micro, very small, small and medium. In the study, the firms that exceed the maximum number of employees for a medium-sized firm were regarded as large. 


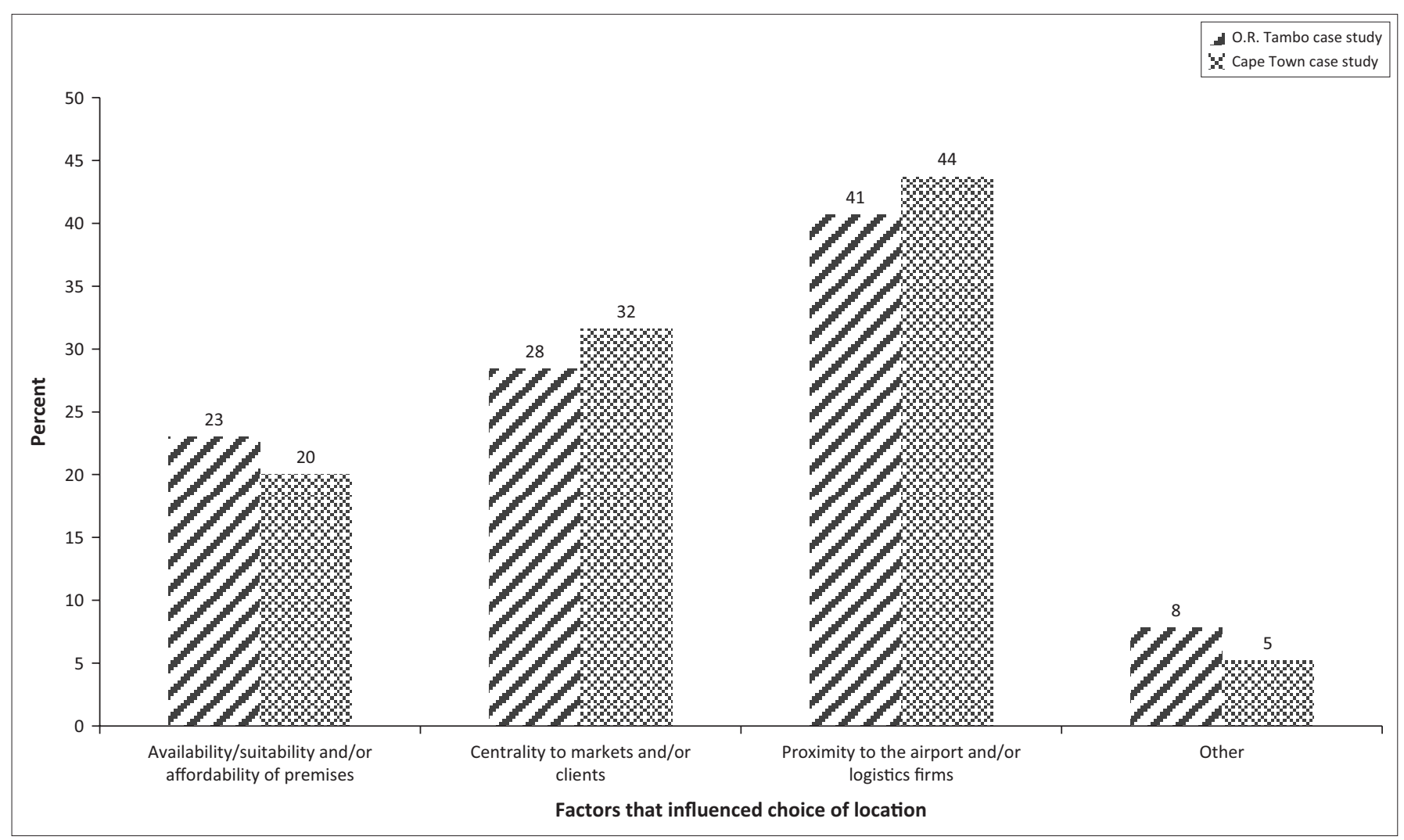

Source: Adapted from Mokhele, M., 2016, 'Spatial economic attributes of airport-centric developments in Cape Town and Johannesburg', Doctoral dissertation, Stellenbosch University, Stellenbosch FIGURE 3: Factors that influenced the airport-centric firms' choice of location.

The largest firm at the O.R. Tambo case study employs 1600 personnel, with a median of 30 for the airport-centric development, while the Cape Town case has a median of 19.5, with 692 personnel employed at the largest firm. The employment numbers recorded for multi-locational firms related to personnel at the case study areas, instead of a firm's total personnel across different locations. At the O.R. Tambo case study, the majority (50\%) of large firms are those engaged in transport, storage and related activities. Similarly, at the Cape Town case study, 32\% of the large firms are those involved in the aforementioned activities. The foregoing findings indicate that logistics firms do not only have prominence in the mix of airport-centric developments but also have a dominant representation as regards large firms. It was important to investigate the size of firms so as to, in part, understand whether the environs of O.R. Tambo and Cape Town airports have propulsive characteristics, that is, the ability of certain economic sectors or firms to dominate and influence the growth of others. It is generally agreed that a large size is one of the attributes that propulsive firms possess.

With the airport-centric firms' mix and size in the background, it was pertinent to investigate reasons that influenced the firms to locate at their current premises. It was discovered that O.R. Tambo and Cape Town international airports are significant forces of attraction because the majority of the firms chose their premises so as to be geographically proximate to the airports and/or transport-oriented firms (see Figure 3). It is important to note that, in the presentation of the findings, the influence of airports and transportoriented firms are combined because in response to a question 'why did your firm choose the current location?' the respondents often conflated the two aspects. The findings show that the intertwined roles of airports and logistics firms are crucial in attracting firms towards the environs of O.R. Tambo and Cape Town airports. Notably, despite O.R. Tambo Airport and its surroundings having being subject of an aerotropolis programme from around 2011, none of the firms interviewed mentioned the programme as having influenced their location choice decisions.

\section{Economies internal to airport-centric firms}

Against the backdrop of O.R. Tambo and Cape Town airports (and their respective logistics firms) being significant forces of attraction in the location of firms, this section investigates elements of internal economies that are potentially reaped by the airport-centric firms. The discussion particularly intends to discover whether the benefits make use of agglomeration economies (based on linkages that largely utilise geographical proximity) or dispersion economies based on linkages that transcend physical proximity and utilise organisational proximity. Internal economies are considered hereunder through a discussion of airport-centric firms that are subsidiaries of multi-locational firms. It should be noted that a multi-locational structure of a firm does not automatically generate internal economies. Retail franchises are a good case in point, given that franchise units do not necessarily have linkages with each other, but rather with their respective head offices. 
TABLE 2: Location of O.R. Tambo airport-centric development's head offices and branches.

\begin{tabular}{lcccccc}
\hline Location & \multicolumn{2}{c}{ Head offices } & & \multicolumn{2}{c}{ Branches } \\
\cline { 2 - 3 } \cline { 6 - 7 } & Frequency & Percentage & & Frequency & Percentage \\
\hline Ekurhuleni & 10 & 12.7 & & 20 & 74 \\
Johannesburg & 20 & 25.3 & & 16 & 5.9 \\
Pretoria & 1 & 1.3 & & 15 & 5.6 \\
Bloemfontein & 0 & 0.0 & & 6 & 2.2 \\
Cape Town & 22 & 27.8 & & 50 & 18.6 \\
Durban & 6 & 7.6 & & 47 & 17.5 \\
East London & 1 & 1.3 & & 8 & 3.0 \\
Port Elizabeth & 3 & 3.8 & & 30 & 11.2 \\
Other locations in South Africa & 4 & 5.1 & & 52 & 19.3 \\
Africa & 0 & 0.0 & & 20 & 7.4 \\
Europe & 7 & 8.9 & & 3 & 1.1 \\
North America & 4 & 5.1 & & 0 & 0.0 \\
South America & 1 & 1.3 & & 0 & 0.0 \\
Asia & 0 & 0.0 & & 1 & 0.4 \\
Australia & 0 & 0.0 & & 1 & 0.4 \\
\hline Total & 79 & 100.0 & $\mathbf{2 6 9}$ & 100.0 \\
\hline
\end{tabular}

Source: Adapted from Mokhele, M., 2016, 'Spatial economic attributes of airport-centric developments in Cape Town and Johannesburg', Doctoral dissertation, Stellenbosch University, Stellenbosch

It was discovered that approximately $61 \%$ of O.R. Tambo airport-centric firms and $76 \%$ of firms at Cape Town airport environs are subsidiaries of multi-locational firms, with potential intra-firm linkages (i.e. excluding franchises). The majority of multi-locational airport-centric firms are transport-oriented, with a significant representation of $19 \%$ of O.R. Tambo airport-centric firms and $34 \%$ of the firms at Cape Town Airport environs.

Of the total multi-locational firms at the cases studied, $60 \%$ at O.R. Tambo Airport environs and $17 \%$ at Cape Town Airport and surrounds are head offices. It was therefore pertinent to investigate the location of the associated head offices or branches to determine whether the multi-locational firms potentially make use of internal economies. For the O.R. Tambo airport-centric development, most head offices of the branch firms are located in the geographically far Cape Town, followed by those in the geographically proximate Johannesburg-Ekurhuleni. For head offices at the case studied, the majority of their branches are located in the geographically far 'other locations in South Africa' (which are beyond the Gauteng city-region) (see Table 2).

Because the Cape Town respondents could, understandably, not distinguish the Johannesburg municipal area from Ekurhuleni municipality, the two were combined to avoid analytical errors. As shown in Table 3, the majority of the head offices of the Cape Town case study's branch firms are located in the geographically distant JohannesburgEkurhuleni area, as are most branches of the head offices.

The foregoing findings show that the multi-locational O.R. Tambo and Cape Town airport-centric firms do not necessarily make use of internal agglomeration economies, but potentially make use of dispersion economies as the linkages (with branches and head offices) are mostly based on organisational proximity extending to geographically far locations.
TABLE 3: Location of Cape Town airport-centric development's head offices and branches.

\begin{tabular}{lcccccc}
\hline Location & \multicolumn{2}{c}{ Head offices } & & \multicolumn{2}{c}{ Branches } \\
\cline { 2 - 3 } \cline { 6 - 7 } \cline { 5 - 7 } & Frequency & Percentage & & Frequency & Percentage \\
\hline Cape Town & 23 & 18.0 & & 7 & 13.2 \\
$\begin{array}{l}\text { Region (other parts of } \\
\text { Western Cape) }\end{array}$ & 3 & 2.3 & & 1 & 1.9 \\
Johannesburg-Ekurhuleni & 75 & 58.6 & & 19 & 35.8 \\
Pretoria & 4 & 3.1 & & 1 & 1.9 \\
Durban & 5 & 3.9 & & 12 & 22.6 \\
Port Elizabeth & 4 & 3.1 & & 6 & 11.3 \\
Other locations in South Africa & 2 & 1.6 & & 3 & 5.7 \\
Africa & 3 & 2.3 & & 3 & 5.7 \\
Europe & 4 & 3.1 & & 1 & 1.9 \\
North America & 2 & 1.6 & & 0 & 0.0 \\
Asia & 1 & 0.8 & & 0 & 0.0 \\
Australia & 2 & 1.6 & & 0 & 0.0 \\
\hline Total & $\mathbf{1 2 8}$ & $\mathbf{1 0 0 . 0}$ & & $\mathbf{5 3}$ & 100.0 \\
\hline
\end{tabular}

Source: Adapted from Mokhele, M., 2016, 'Spatial economic attributes of airport-centric developments in Cape Town and Johannesburg', Doctoral dissertation, Stellenbosch developments in Cape
University, Stellenbosch

\section{External linkages of airport-centric firms}

\section{Linkages with O.R. Tambo and Cape Town airports}

The majority of airport-centric firms' utilise their respective airports. This attribute shows that the firms make use of geographical proximity to the airports, and potentially benefit from agglomeration economies. At the O.R. Tambo Airportcentric development, $73 \%$ of the firms make use of the airport for air passenger services and/or airfreight. Because the study area is enclosed within a radius of about $5 \mathrm{~km}$, it is argued that the firms potentially make use of urbanisation economies. Most of those firms ( $25 \%$ of total case study firms) are involved in transport, storage and related activities, followed by manufacturing-oriented firms (see Table 4).

At the Cape Town case studied, approximately $70 \%$ of the firms make use of the airport for air passenger services and/ or airfreight. Given that the study area is within approximately $2.5 \mathrm{~km}$ radius of the airport, this finding partially shows that the firms potentially make use of urbanisation economies by virtue of being located in the geographical proximity of the airport. Similar to the O.R. Tambo case studied, the majority of those (representing a significant $33 \%$ of total case study firms) are firms involved in transport, storage and related activities; followed by wholesale and retail firms (see Table 4).

In light of the high general usage of the two airports noted above, it is important to observe that, significantly, $44 \%$ of the O.R. Tambo airport-centric population and $45 \%$ of the Cape Town population specifically use their airports for airfreight services. However, as one of the limitations of the study, the investigations conducted could not determine the frequency of usage and volumes of cargo transported. The majority of firms with linkages with the respective airports are transport-oriented, representing $28 \%$ of total firms at the O.R. Tambo case studied and 32\% of total firms at Cape Town Airport and environs. This high utilisation shows that airfreight is an important component of the airport-centric developments, in part supporting the argument that O.R. Tambo and Cape Town airports are 
TABLE 4: O.R. Tambo and Cape Town airport-centric firms' use of the airports.

\begin{tabular}{|c|c|c|c|c|c|c|c|}
\hline \multirow[t]{2}{*}{ Type of firm } & \multirow[t]{2}{*}{ Frequency and percentage } & \multicolumn{2}{|c|}{ Use of O.R. Tambo Airport } & \multirow[t]{2}{*}{ Total } & \multicolumn{2}{|c|}{ Use of Cape Town Airport } & \multirow[t]{2}{*}{ Total } \\
\hline & & Yes & No & & Yes & No & \\
\hline \multirow[t]{3}{*}{ Manufacturing } & Count & 64.0 & 16.0 & 80.0 & 20.0 & 7.0 & 27.0 \\
\hline & $\%$ within type of firm & 80.0 & 20.0 & 100.0 & 74.1 & 25.9 & 100.0 \\
\hline & $\%$ of Total & 20.9 & 5.2 & 26.1 & 9.4 & 3.3 & 12.7 \\
\hline \multirow{2}{*}{$\begin{array}{l}\text { Transport, storage and } \\
\text { related activities }\end{array}$} & Count & 76.0 & 9.0 & 85.0 & 69.0 & 14.0 & 83.0 \\
\hline & $\%$ within type of firm & 89.4 & 10.6 & 100.0 & 83.1 & 16.9 & 100.0 \\
\hline \multirow[t]{3}{*}{ Wholesale and retail } & Count & 56.0 & 34.0 & 90.0 & 27.0 & 27.0 & 54.0 \\
\hline & $\%$ within type of firm & 62.2 & 37.8 & 100.0 & 50.0 & 50.0 & 100.0 \\
\hline & $\%$ of Total & 18.3 & 11.1 & 29.4 & 12.7 & 12.7 & 25.5 \\
\hline \multirow[t]{3}{*}{ Accommodation and catering } & Count & 3.0 & 6.0 & 9.0 & 3.0 & 1.0 & 4.0 \\
\hline & $\%$ within type of firm & 33.3 & 66.7 & 100.0 & 75.0 & 25.0 & 100.0 \\
\hline & $\%$ of Total & 1.0 & 2.0 & 2.9 & 1.4 & 0.5 & 1.9 \\
\hline \multirow{2}{*}{$\begin{array}{l}\text { Car repair, tyre dealer, testing } \\
\text { and repair of machinery }\end{array}$} & Count & 7.0 & 8.0 & 15.0 & 7.0 & 4.0 & 11.0 \\
\hline & $\%$ of Total & 2.3 & 2.6 & 4.9 & 3.3 & 1.9 & 5.2 \\
\hline \multirow[t]{3}{*}{ Other } & Count & 17.0 & 10.0 & 27.0 & 23.0 & 10.0 & 33.0 \\
\hline & $\%$ within type of firm & 63.0 & 37.0 & 100.0 & 69.7 & 30.3 & 100.0 \\
\hline & $\%$ of Total & 5.6 .0 & 3.3 & 8.8 & 10.8 & 4.7 & 15.6 \\
\hline \multirow[t]{2}{*}{ Total } & Count & 223.0 & 83.0 & 306.0 & 149.0 & 63.0 & 212.0 \\
\hline & $\%$ of Total & 72.9 & 27.1 & 100.0 & 70.3 & 29.7 & 100.0 \\
\hline
\end{tabular}

Source: Adapted from Mokhele, M., 2016, 'Spatial economic attributes of airport-centric developments in Cape Town and Johannesburg', Doctoral dissertation, Stellenbosch University, Stellenbosch

TABLE 5: Location of firms subcontracted by the airport-centric firms.

\begin{tabular}{lcccccc}
\hline \multirow{2}{*}{$\begin{array}{l}\text { Location of subcontracted } \\
\text { firms }\end{array}$} & \multicolumn{2}{c}{ O.R. Tambo } & & \multicolumn{2}{c}{ Cape Town } \\
\cline { 2 - 3 } \cline { 6 - 7 } \cline { 5 - 6 } & Frequency & Percentage & & Frequency & Percentage \\
\hline On or around the airport & 51 & 30.5 & & 55 & 25.5 \\
Elsewhere in the city & 71 & 42.5 & & 73 & 33.8 \\
In the city-region & 21 & 12.6 & & 41 & 19.0 \\
Elsewhere in South Africa & 18 & 10.8 & & 32 & 14.8 \\
Outside South Africa & 6 & 3.6 & & 15 & 6.9 \\
\hline Total & $\mathbf{1 6 7}$ & $\mathbf{1 0 0 . 0}$ & & $\mathbf{2 1 6}$ & $\mathbf{1 0 0 . 0}$ \\
\hline
\end{tabular}

Source: Adapted from Mokhele, M., 2016, 'Spatial economic attributes of airport-centric developments in Cape Town and Johannesburg', Doctoral dissertation, Stellenbosch University, Stellenbosch

potentially import or export-oriented trans-shipment locations that link the sources of inputs, manufacturers and markets. However, the use of the airport for airfreight is not consistent across the different firms, given a significant correlation (at the 0.01 level, two-tailed for O.R. Tambo and 0.05 level, one-tailed for Cape Town) calculated between the type of firm and the use of the airports for airfreight. This correlation shows that the change in the activities of a firm can potentially affect the magnitude at which the two airports are used for airfreight purposes, with logistics firms dominating such linkages.

It is further important to note that the airport-centric couriers and freight forwarders assist the neighbouring firms to fulfil their shipping requirements. For instance, as regards the airport-centric manufacturing firms that utilise the airports for airfreight, $73 \%$ at O.R. Tambo Airport and $100 \%$ at the environs of Cape Town Airport ship through the neighbouring couriers and freight forwarders. These findings therefore show that although the O.R. Tambo and Cape Town airport-centric firms potentially benefit from urbanisation economies, they reap the benefits through the assistance and catalytic role of the neighbouring logistics firms.

\section{Linkages with other firms}

As a further sign of linkages that use geographical proximity, $74 \%$ of firms at O.R. Tambo environs and $72 \%$ of Cape Town airport-centric firms have business linkages with the neighbouring firms. Though the investigations could not explicitly distinguish between the different linkages, they could be upstream, downstream and/or lateral and show that some of the aforementioned firms potentially benefit from elements of external economies. The majority of firms that have linkages with neighbouring firms are transportoriented, representing a significant $25 \%$ (of total firms) at the environs of O.R. Tambo Airport and 35\% of total firms at Cape Town Airport and surrounds.

Generally, there are different ways that co-operation and linkages between independent firms are realised, and frequently take place within the framework of subcontracting. Showing a potential existence of horizontal linkages, subcontracting is one of the arrangements used by airportcentric firms for inter-firm linkages within the case study areas, metropolitan areas, city-regions, other parts of the country and beyond: wherein the airport-centric firms use the services of other firms and/or offer their services to others. It should be noted that during the survey interviews, the respondents were explicitly informed that the subcontracting investigated relates to the firm's core business. For instance, cleaning activities would not be regarded as a subcontracting activity for a firm that is not in the business of cleaning. Approximately $30 \%$ of O.R. Tambo airport-centric firms and $44 \%$ of Cape Town airport-centric firms utilise the services of other firms and potentially make use of subcontracting agglomeration benefits that are stronger at the metropolitan area than at airports and surrounds (see Table 5).

Relatively fewer airport-centric firms assist other firms through subcontracting, that is, about $15 \%$ of O.R. Tambo 
TABLE 6: Location of firms that subcontract the airport-centric firms.

\begin{tabular}{lcccccc}
\hline \multirow{2}{*}{$\begin{array}{l}\text { Location of firms that } \\
\text { subcontract airport-centric firms }\end{array}$} & \multicolumn{2}{c}{ O.R. Tambo } & & \multicolumn{2}{c}{ Cape Town } \\
\cline { 2 - 3 } \cline { 6 - 7 } & Frequency & Percentage & & Frequency & Percentage \\
\hline On or around the airport & 19 & 12.5 & & 29 & 19.9 \\
Elsewhere in the city & 55 & 36.2 & & 39 & 26.7 \\
In the city-region & 20 & 13.2 & & 33 & 22.6 \\
Elsewhere in South Africa & 19 & 12.5 & & 28 & 19.2 \\
\hline Outside South Africa & 39 & 25.7 & & 17 & 11.6 \\
\hline Total & $\mathbf{1 5 2}$ & $\mathbf{1 0 0 . 0}$ & & $\mathbf{1 4 6}$ & $\mathbf{1 0 0 . 0}$ \\
\hline
\end{tabular}

Source: Adapted from Mokhele, M., 2016, 'Spatial economic attributes of airport-centric developments in Cape Town and Johannesburg', Doctoral dissertation, Stellenbosch University, Stellenbosch

firms and $22 \%$ of Cape Town firms. The subcontracting linkages of those firms potentially generate agglomeration benefits that are slightly stronger at the metropolitan area and region than at the airport environs (see Table 6).

\section{Linkages with airport-centric firms elsewhere}

Although the current discussion has similarities with the previous Linkages with Other Firms section, it focuses exclusively on the linkages (both intra-firm and inter-firm) of O.R. Tambo and Cape Town airport-centric firms with airport-centric firms elsewhere. Through organisational proximity, $18 \%$ of O.R. Tambo airport-centric firms and $48 \%$ of Cape Town airport-centric firms maintain linkages with airport-centric firms elsewhere in South Africa. Of those firms, $77 \%$ at O.R. Tambo and surrounds and $62 \%$ at the Cape Town case study are transport-oriented. Notably, none of the linkages occur within the city-regions, and arguably testament to the fact that linkages between airport-centric developments do not use geographical proximity.

For inter-country linkages, $13 \%$ of O.R. Tambo airport-centric firms and $21 \%$ of Cape Town airport-centric firms have linkages with airport-centric firms located outside South Africa. Of those firms with inter-country linkages, 90\% at O.R. Tambo Airport and $89 \%$ at Cape Town Airport are transport-oriented. Given the great distances between O.R. Tambo Airport, Cape Town Airport and other Airports beyond South African borders, the aforementioned intraand inter-country linkages do not generate agglomeration economies. However, as one of the limitations of the study, investigations were not undertaken on the nature of relationships that the cases studied have with airport-centric developments elsewhere, and the global economy at large.

\section{Synthesis and conclusion}

The article investigated the spatial economic attributes of O.R. Tambo and Cape Town airports and environs (referred to as airport-centric developments), with a particular emphasis on the role of transport-oriented firms. The article advanced and applied an analytical approach that explores interconnections between the concepts of linkages, agglomeration economies and clustering; and the relationally interpreted economic space, proximity and firm. Because of the airport-centric firms' linkages with the respective airports and neighbouring firms, O.R. Tambo and Cape Town airport-centric developments are arguably spatially clustered. Furthermore, because of the linkages with airport-centric firms elsewhere in South Africa and beyond, it is argued that O.R. Tambo and Cape Town airport-centric developments are potentially components of an import or export organisational cluster of airport-centric developments. Different elements of that organisational cluster are part of the same economic space, regardless of their distinct geographical locations. As regards further studies, it is proposed that the foregoing findings (which can be improved upon with work on other case studies) be used as bases for extending a theoretical framework that describes and explains the spatial economic forces that drive airport-centric developments.

\section{Acknowledgements}

Financial support of the National Research Foundation (NRF) towards this study is acknowledged. Opinions and conclusions arrived at are those of the author and are not necessarily to be attributed to the NRF. The author acknowledges the constructive comments of the reviewers and the editorial team.

\section{Competing interests}

The author declares that he has no financial or personal relationships that may have inappropriately influenced him in writing this article.

\section{References}

Airports Company South Africa (ACSA), 2014a, Cape Town International Airport: Airlines, shops, restaurants and services database, viewed 09 June 2014, from http://www.acsa.co.za

Airports Company South Africa (ACSA), 2014b, OR Tambo International Airport: Airlines, shops, restaurants and services database, viewed 09 June 2014, from http://www.acsa.co.za

Airports Company South Africa (ACSA), 2018a, O.R. Tambo International Airport viewed 23 March 2018, from http://www.airports.co.za/airports/or-tambointernational

Airports Company South Africa (ACSA), 2018b, Cape Town International Airport, viewed 23 March 2018, from http://www.airports.co.za/airports/cape-towninternational

Airport Industria CID (City Improvement District), 2013, Business directory, viewed 01 October 2013, from http://www.airportcid.co.za

Appold, S.J., 2015, 'The impact of airports on US urban employment distribution', Environment and Planning A 47(2), 412-429. https://doi.org/10.1068/a130114p

Appold, S.J. \& Kasarda, J.D., 2013, 'The airport city phenomenon: Evidence from large US airports', Urban Studies 50(6), 1239-1259. https://doi.org/10.1177/00420 98012464401

Blanton, W., 2004, 'On the airfront', Planning 70(5), 34-35.

Cape Town Chamber of Commerce, 2014, Company directory, viewed 01 May 2014, from http://www.capechamber.co.za

Coetzee, P.J.V.V. \& Swanepoel, P.A., 2017, 'Spatial relationship and movement patterns of the air cargo industry in airport regions', Journal of Transport and Supply Chain Management 11, 1-10. https://doi.org/10.4102/jtscm.v11i0.297

Conventz, S.C.M., 2010, 'New office space at international hub airports. Evolving urban patterns at Amsterdam and Frankfurt/M', in U. Knippernberger \& A. Wall (eds.), Airports in cities and regions: Research and practice, pp. 57-67, KIT Scientific Publishing, Karlsruhe.

Conway, M., 1993, Airport cities 21: The new global transport centers of the 21st century, Conway Data, Atlanta, GA.

De Jong, B., Suau-Sanchez, P. \& Droß, M., 2008, 'The underestimated airport region: Reflecting on planning policies in the airport regions of Amsterdam, Barcelona and Munich', Aerlines Magazine, Airport \& Planning Policy: e-zine edn. 41, viewed 09 May 2012, from http://www.aerlines.nl

East Rand Chamber of Commerce, 2014, East Rand Chamber of Commerce and Industry datadex, viewed 07 April 2014, from http://www.chamberlink.co.za

Freestone, R. \& Baker, D., 2011, 'Spatial planning models of airport-driven urban development', Journal of Planning Literature 26(3), 263-279. https://doi. org/10.1177/0885412211401341 
Galvin, V., 2010, 'Coordinating spatial development in airport regions. Embeddedness and experimentation at Paris Orly and Amsterdam Schiphol', Aerlines 48, 1-5.

Giuliano, G. \& Small, K., 1991, 'Subcentres in the Los Angeles region', Regional Science and Urban Economics 21(2), 163-182. https://doi.org/10.1016/01660462(91)90032-I

Giuliano, G. \& Small, K., 1999, 'The determinants of growth of employment subcentres', Journal of Transport Geography 7(3), 189-201. https://doi. org/10.1016/S0966-6923(98)00043-X

Hoare, A.G., 1974, 'International airports as growth poles: A case study of Heathrow airport', Transactions of the Institute of British Geographers 63, 75-96. https:// doi.org/10.2307/621533

Hoare, A.G., 1975, 'Foreign firms and air transport: The geographical effect of Heathrow airport', Regional Studies 9(4), 349-367. https://doi. org/10.1080/09595237500185391

Isard, W., 1956, Location and space-economy: A general theory relating to industria location, market areas, land use, trade, and urban structure, The Massachusetts Institute of Technology Press, Cambridge, MA.

Jofre-Monseny, J., Marín-López, R. \& Viladecans-Marsal, E., 2011, 'The mechanisms of agglomeration: Evidence from the effect of inter-industry relations on the location of new firms', Journal of Urban Economics 70(2-3), 61-74. https://doi. of new firms', Journal of Urbo
org/10.1016/j.jue.2011.05.002

Jofre-Monseny, J., Marín-López, R. \& Viladecans-Marsal, E., 2014, 'The determinants of localization and urbanization economies: Evidence from the location of new firms in Spain', Journal of Regional Science 54(2), 313-337. https://doi. org/10.1111/jors.12076

Karlsson, C., Johansson, B. \& Stough, R.R., 2005, 'Industrial clusters and inter-firm networks: An introduction', in C. Karlsson, B. Johansson \& R.R. Stough (eds.), Industrial clusters and inter-firm networks, pp. 1-28, Edward Elgar, Cheltenham.

Karlsson, J., Ludders, R.J., Wilde, D., Mochrie, D. \& Seymour, C., 2008, Airport economic impact methods and models. A synthesis of airport practice, Transportation Research Board, Washington, DC.

Kasarda, J.D., 1998, 'The global transpark: Infrastructure for industrial advantages', Urban Land 57(4), 107-110.

Kasarda, J.D., 2009, 'Airport cities', Urban Land 68(4), 56-60.

Kasarda, J.D. \& Lindsay, G., 2011, Aetrotropolis: The way we'll live next, Penguin Group, London.

Keeble, D.E., 1968, 'Airport location, exporting, and industrial growth', Town and Country Planning 36(4), 209-214.

Knippenberger, U., 2010, 'Airport-region governance. Conundrums of airports and regional coherence', in U. Knippenberger \& A. Wall (eds.), Airports in cities and regions: Research and practice, pp. 101-111, KIT Scientific Publishing, Karlsruhe.

Knippenberger, U., 2015, 'Airports and their regions: A reciprocal affair of spatia conflicts and economic development', in S. Conventz \& A. Thierstein (eds.), Airports, cities and regions, pp. 86-101, Routledge, Oxon.

Krupka, D.J., 2009, Some evidence on the nature of urbanization economies, Discussion Paper No. 4573, University of Michigan and IZA, Bonn.

Leedy, P.D. \& Ormrod, J.E., 2010, Practical research: Planning and design, 9th edn., Pearson, Upper Saddle River, NJ.

Malmberg, A. \& Maskell, P., 2002, 'The elusive concept of localization economies: Towards a knowledge-based theory of spatial clustering', Environment and Planning A 34(3), 429-449. https://doi.org/10.1068/a3457

Marshall, A., 1920, Principles of economics: An introductory volume, 8th edn. Macmillan and Co., London.

McMillen, D.P. \& McDonald, J.F., 1998, 'Suburban subcentres and employment density in metropolitan Chicago', Journal of Urban Economics 43(2), 157-180. https://doi.org/10.1006/juec.1997.2038

Mestre, V., 2008, Effects of aircraft noise: Research update on selected topics. A synthesis of airport practice, Transportation Research Board, Washington, DC.

Mokhele, M., 2016, 'Spatial economic attributes of airport-centric developments in Cape Town and Johannesburg', Doctoral dissertation, Stellenbosch University, Stellenbosch.

Mokhele, M., 2017, 'Spatial economic evolution of the airport-centric developments of Cape Town and OR Tambo international airports in South Africa', Town and Regional Planning 70, 26-36, viewed 15 December 2017, from http://journals.ufs. ac.za/index.php/trp/article/view/593

Neuman, W.L., 2000, Social research method: Qualitative and quantitative approaches, 4th edn., Allyn and Bacon, Needham Heights, MA.

Ottaviano, G.I.P. \& Thisse, J.F., 2004, 'Agglomeration and economic geography, 4th vol.', in V. Henderson \& J.F. Thisse (eds.), Handbook of regional and urban economics, pp. 2563-2608, North-Holland Publishing Company, Amsterdam.

Panzar, J.C. \& Willig, R.D., 1981, 'Economies of scope', American Economic Review $71(2), 268-272$
Parr, J.B., 2002, 'Missing elements in the analysis of agglomeration economies', International Regional Science Review 25(2), 151-168, https://doi. org/10.1177/016001702762481221

Polenske, K.R., 2008, 'Clustering in space versus dispersing over space', in C. Karlsson (ed.), Handbook of research on cluster theory, pp. 133-149, Edward Elgar, Cheltenham.

Porter, M.E., 1990, The competitive advantage of nations, Free Press, New York.

Prosperi, D.C., 2007, 'Airports as centres of economic activity: Empirical evidence from three US metropolitan areas', Paper presented at the REAL CORP 007, Vienna, 20th-23rd May, viewed 09 May 2011, from http://www.corp.at

Prosperi, D.C., 2008, 'MIA: Miami International Airport or Miami innovation area', Paper presented at the REAL CORP 008, Vienna, 19th-21st May, viewed 20 June 2013, from http://www.corp.at

Republic of South Africa, 1996, National small business Act, Act 102 of 1996, viewed 24 August 2015, from https://www.thedti.gov.za/sme_development/docs/act.pdf

Rogerson, C.M., 1998, 'High-technology clusters and infrastructure development: International and South African experiences', Development Southern Africa 15 875-905. https://doi.org/10.1080/03768359808440054

Rosenthal, S.S. \& Strange, W.C., 2003, 'Geography, industrial organization, and agglomeration', The Review of Economics and Statistics 85(2), 377-393. https:// doi.org/10.1162/003465303765299882

Schlaack, J., 2010, 'Defining the Airea. Evaluating urban output and forms of interaction between airport and region', in U. Knippernberger \& A. Wall (eds.), Airports in cities and regions: Research and practise, pp. 113-125, KIT Scientific Airports in cities and
Publishing, Karlsruhe.

Scott, A.J., 1988, New industrial spaces: Flexible production organization in North America and Western Europe, Pion, London.

Shukla, V. \& Waddell, P., 1991, 'Firm location and land use in discrete urban space. A study of the spatial structure of Dallas-Fort Worth', Regional Science and Urban Economics 21(2), 225-253. https://doi.org/10.1016/0166-0462(91)90035-L

Sit, V., 2004, 'Global transpark: New competitiveness for Hong Kong and South China based on air logistics', Geografiska Annaler. Series B, Human Geography 86(3), 145-163. https://doi.org/10.1111/j.0435-3684.2004.00159.x

Sivitanidou, R., 1996, 'Warehouse and distribution facilities and community attributes: An empirical study', Environment and Planning A 28(7), 1261-1278. https://doi. org/10.1068/a281261

Smith, D.M., 1977, Patterns in human geography, Penguin Books, Middlesex.

Sohn, J., 2004, 'Information technology in the 1990s: More footloose or more location-bound', Papers in Regional Science 83(2), 467-485. https://doi. org/10.1111/j.1435-5597.2004.tb01918.x

Statistics South Africa, 2012, Standard industrial classification of all economic activities (SIC), 7th edn., Statistics South Africa, Pretoria.

Trudon, 2012a, The phone book: Cape Peninsula 2012/2013, Trudon, Johannesburg.

Trudon, 2012b, Yellow pages: Cape Peninsula 2012/2013, Trudon, Johannesburg.

Trudon, 2013, Yellow pages business database, viewed 17 April 2013, from http:// www.yellowpages.co.za

Vahaly, J., 1976, 'The location of service and office activities in Nashville-Davidson County, 1970', Land Economics 54(4), 479-492. https://doi.org/10.2307/3145191

Van Boxtel, M. \& Huys, M., 2005, 'Unravelling decision making about the future developments of Amsterdam Airport Schiphol', Paper prepared for the 45th European Regional Science Association, Amsterdam, 23rd-27th August.

Van Wijk, M., 2007, 'Airports as cityports in the city-region', Doctoral thesis, Utrecht University, Utrecht.

Van Wijk, M., 2008, 'Development of airport regions: Varieties of institutions in Schiphol and Frankfurt', Aerlines Magazine, Airports: e-zine edn. 40, viewed 12 August 2011, from http://www.aerlines.n

Van Wyk, M., 2013, The Kempton Park website: Directory, viewed 12 June 2013, from http://www.kemptalk.com

Venables, A.J., 1996, 'Equilibrium locations of vertically linked industries', Internationa Economic Review 37(2), 341-359. https://doi.org/10.2307/2527327

Walker, A.R. \& Baker, D.C., 2010, 'A planning support system for airport city development', Paper presented at the 14th Air Transport Research Society Conference, Porto, 06-09th July.

Walker, A.R. \& Stevens., N.J., 2008, 'Airport city development in Australia: Land use classification and analyses' Paper presented at the 10th TRAIL Congress and Knowledge Market, Rotterdam, 14-15th October.

Warffemius, P.M.J., 2007, 'Modelling the clustering of distribution centres around Amsterdam Airport Schiphol. Location endowments, economic agglomeration, locked-in logistics and policy implications', Doctoral dissertation, The Netherlands TRAIL Research School. 